\title{
Analysis of the Relationship Between Industry Concentration and GDP Growth: China's Property Insurance Industry
}

\author{
Qianqian $\mathrm{Li}^{*}$
}

School of Economics, Xiamen University, Siming South Road 422, 361005, Xiamen, China

\begin{abstract}
This paper examines the impact of the concentration of the property insurance industry on economic growth in China. We first compute the Herfindahl-Hirschman Index (HHI) for the Chinese property insurance industry and establish a two-step system of generalized methods of moments (Two-Step SYS-GMM) estimation to compute the economic effect using a unique data set from the years 1980 to 2014. The results show that while industry concentration appears to have decelerated in recent years, the property insurance market in China is still a comparatively oligopolistic market. Moreover, the HHI has a significantly negative impact on gross domestic product, and lowering the HHI could lead to higher economic growth.
\end{abstract}

Keywords: GDP growth, GMM, HHI, industry, property insurance.

\section{INTRODUCTION}

There are two basic characteristics in the development of property insurance in China: first, total premiums grow very rapidly with unbalanced development in the types of insurance [1]; and second, though the degree of industrial agglomeration decreased, this cannot fundamentally reverse the monopolistic structure. Previous research into the relationship between the degree of agglomeration in the property insurance industry and economic growth has provided consistent conclusions. Neither industrial agglomeration nor economic growth can exist effectively without the other [2]. The increase in industrial clusters can promote industrial growth [3,4]. Endogeneity was considered to establish a dynamic panel regression model to test data from the European Union, which supported the conclusion above [5]. However, a study found that an increase in industrial agglomeration has an adverse effect on economic growth [6]. In China, researchers proved that economic growth could be stimulated by the development of the property insurance industry [7]. Other scholars did not find a significant relationship between industrial agglomeration in the property insurance industry and economic growth [8]. Tian and Gao [9] concluded that China's insurance industry provided economic stability rather than economic growth between 1999 and 2009 using a vector error correction model and quarterly insurance market and GDP data. Thus, there are only a few studies focusing on the degree of industrial agglomeration in property insurance and its relationship to economic growth, especially in China. Besides, most domestic scholars ignore the endogenous problem of the model in examing the relationship between industrial agglomeration in property insurance and economic growth. For example, the interaction between economic growth and other factors hinders accuracy and acceptability.
This study aims to contribute three main improvements to the discussion. Firstly, this study uses a novel research perspective that departs from previous research into insurance, profitability, and management. This is accomplished by introducing a Chinese regional index (HHI) of industrial clusters to measure the size of monopoly power in the property insurance market to accurately analyze the effect of $\mathrm{HHI}$ on economic growth in China. Secondly, this study improves upon research methods to guarantee a high level of data integrity and consistency by using time series regression analysis. Reliability is further confirmed by addressing heteroskedasticity and endogeneity by analyzing results using the GMM method. The findings indicate that the expansion of the property insurance business has a significant impact on economic growth. However, its economic stimulus effect could be improved by reducing the degree of industrial agglomeration.

The rest of this paper is organized as follows. Section two sets up a regression model and defines the empirical specification. Section three presents and analyzes the estimation results using a two-step system of generalized methods of moments (Two-Step SYS-GMM). The fourth section concludes the paper with a summary of the results.

\section{EMPIRICAL SPECIFICATION}

\subsection{Model Specification}

To study the relationship between the degree of industrial agglomeration in the property insurance industry and economic growth, and introducing the time dimension, we establish Equation (1):

$$
\mathrm{GDP}_{\mathrm{t}}=\beta_{0}+\beta_{1} \mathrm{HHI}_{\mathrm{t}}+\beta_{2} \text { Premium }_{\mathrm{t}}+\beta_{3} \text { Export }_{\mathrm{t}}+\mathrm{u}_{\mathrm{t}}
$$

where $t$ is the period. The dependent variable GDP is the cumulative total gross domestic product, (GDP) at current prices each year. GDP is the core index of national economic accounting that measures a country or region's overall economic situation. The independent variables are the Chinese 
Table 1. 1990-2010 ratio of premiums for each type of insurance to total premiums annually (\%).

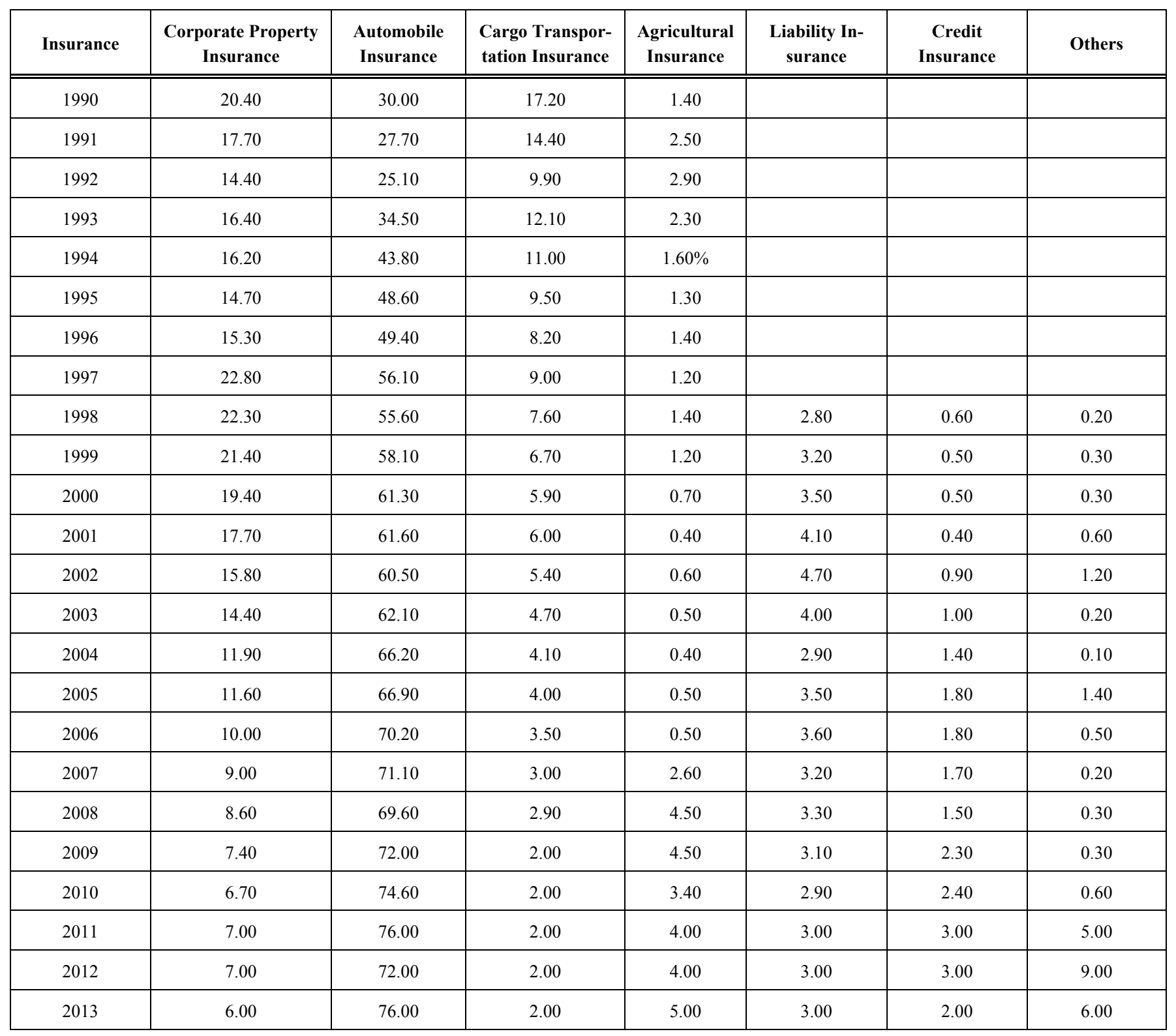

The data is sourced from both the China Statistical Yearbook , China Insurance Yearbook and Almanac of China's Finance and Banking.

regional index of industrial clusters (HHI), the total property insurance premiums paid by all owners of insured properties to maintain their policies (Premium), and total export volume (Export). Table 1 shows the comprehensive development of property insurance from 1980-2010. Generally, automobile insurance grew the fastest, taking around two thirds of the total market share. Agriculture insurance has expanded recently through support from Chinese Government. Both corporate property and cargo transportation insurance has decreased dramatically, indicating a decline in growth relative to GDP growth. As exports are included in the GDP, a higher GDP indicates a greater probability for Chinese officials to increase exports, though a reverse causality still exists between GDP and exports. Consequently, this study uses two instrumental variables to eliminate the problem of endogeneity, the first- and second-order lag variables of total fixed assets investment volume (Finvest) each year.Fixed assets investment and GDP growth can stimulate each other for common development $[7,10,11]$.

Market agglomeration are the parameters to assess the entire industry, the most important and essential factor reflecting the level of market competition and monopoly. There are two typical kinds of appraisal parameters: $\mathrm{CR}_{\mathrm{m}}$ and the Herfindahl-Hirschman Index (HHI, Equation (2)). $\mathrm{CR}_{\mathrm{m}}$ represents the degree of industrial concentration by calculating the market shares of the top $\mathrm{K}$ companies in a particular market (Equation (3)). This study assess the top four companies $(\mathrm{K}=4)$. The results in Table 2 indicate that the property insurance market in China is oligopolistic. $\mathrm{CR}_{4}$ exceeded $85 \%$ in 2004 , and was thus an Oligopoly I type market. Although the level has been in decline since 2005, its pace is rather slow. The higher the value of $\mathrm{CR}_{4}$, the stronger the power of the top $\mathrm{K}$ companies. So using $\mathrm{CR}_{4}$ has 
Table 2. Market structure classification (Bain).

\begin{tabular}{|c|c|c|c|}
\hline Market structure & Concentration (\%) & Market structure & Concentration (\%) \\
\hline \hline Oligopoly I & $\mathrm{CR}_{4} \geq 85$ & Oligopoly IV & $35 \leq \mathrm{CR}_{4}<35$ \\
\hline Oligopoly II & $75 \leq \mathrm{CR}_{4}<85$ & Oligopoly V & $30 \leq \mathrm{CR}_{4}<35$ \\
\hline Oligopoly III & $50 \leq \mathrm{CR}_{4}<50$ & Competition & $\mathrm{CR}_{4}<30$ \\
\hline
\end{tabular}

Source: [12-13]

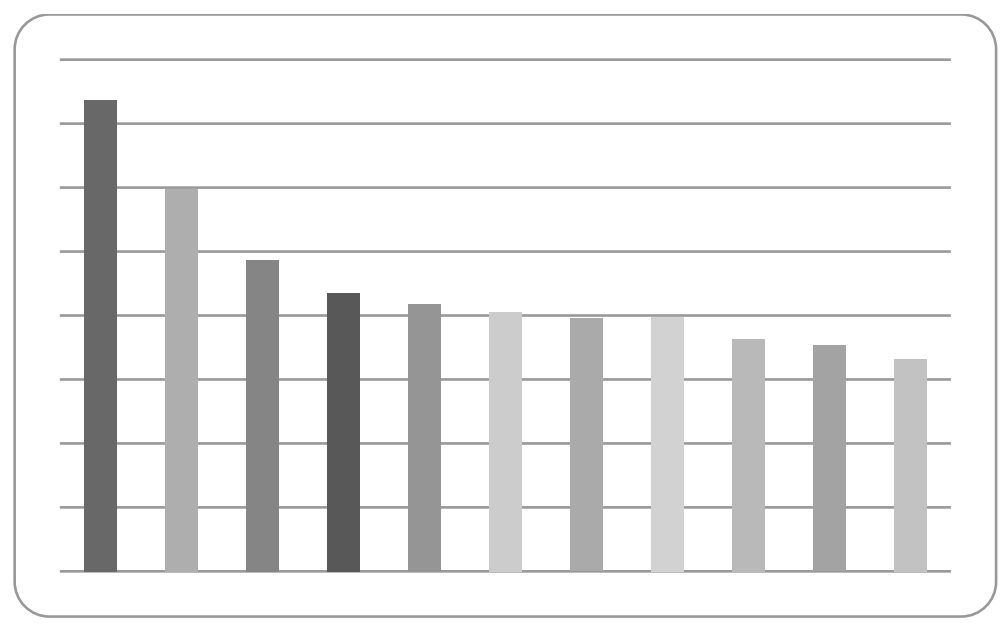

Fig. (1). HHI of the property insurance industry in China.

the advantage of showing market agglomeration according to the total premiums intuitively. However, this parameter simply sums of shares of the top K companies, and does not reflect the impact of the distribution of market power concentration for each property insurance company.

Thus, Equation 1 uses HHI, which is the sum of the market share for each of the firms in an industry to measure market competition. In general, a higher HHI indicates a higher degree of concentration within an industry. There are two advantages to using HHI. First, this index is very sensitive to the distribution in an industry, in this case property insurance, which can comprehensively reflect the total number and relative scale of enterprises. Second, to arrive at more realistic conclusions, companies with larger market share will obtain a greater weight in terms of analyzing the market share gap for each company in the property insurance industry. HHI measures the variation in market shares that indicate the degree of a company's scale in the market. Compared to property insurance markets in developed countries or regions, Fig. (1) shows that HHI in China has declined by two thirds since 1985 . However, the property insurance market in China is still an oligopoly because of its high concentration.

$$
\begin{aligned}
& \mathrm{HHI}=\sum_{\mathrm{i}=1}^{\mathrm{n}}\left(\frac{X_{i}}{\sum_{i=1}^{n} X_{i}}\right)^{2}=\sum_{\mathrm{i}=1}^{\mathrm{n}} \mathrm{S}_{\mathrm{i}}^{2} \\
& \mathrm{HHI}=\sum_{\mathrm{i}=1}^{\mathrm{n}}\left(\frac{X_{i}}{\sum_{i=1}^{n} X_{i}}\right)^{2}=\sum_{\mathrm{i}=1}^{\mathrm{n}} \mathrm{S}_{\mathrm{i}}^{2} \\
& \mathrm{CR}_{\mathrm{m}}=\sum_{\mathrm{i}=1}^{\mathrm{m}} \frac{\left(\mathrm{X}_{\mathrm{i}}\right)_{\mathrm{m}}}{\sum_{\mathrm{i}=1}^{\mathrm{n}}\left(\mathrm{X}_{\mathrm{i}}\right)_{\mathrm{n}}}=\sum_{\mathrm{i}=1}^{\mathrm{m}} \mathrm{S}_{\mathrm{i}}
\end{aligned}
$$

where $\mathrm{m}$ is the number of the largest enterprises in the property insurance industry; nis the number of all enterprises in the property insurance industry; $X_{i}$ is the scale of a certain enterprise ; and $\mathrm{S}_{\mathrm{i}}$ is the market share of the $i^{\text {th }}$ enterprise.

Finally, taking different the units of the variables into consideration, we create Equation (4) by taking the logarithm of variables to analyze the impact of HHI on economic growth in China:

$$
\begin{aligned}
& \operatorname{lnGDP} \mathrm{t}_{\mathrm{t}}=\beta_{0}+\beta_{1} \operatorname{lnHHI}_{\mathrm{t}}+\beta_{2} \operatorname{lnPremium}_{\mathrm{t}}+\beta_{3} \operatorname{lnExport}_{\mathrm{t}}+\mathrm{u}_{\mathrm{t}} \\
& \operatorname{lnGDP}_{\mathrm{t}}=\beta_{0}+\beta_{1} \operatorname{lnHHI}_{\mathrm{t}}+\beta_{2} \operatorname{lnPremium}_{\mathrm{t}}+\beta_{3} \operatorname{lnExport}_{\mathrm{t}}+ \\
& \mathrm{u}_{\mathrm{t}} \operatorname{lnGDP}_{\mathrm{t}}=\beta_{0}+\beta_{1} \operatorname{lnHHI}_{\mathrm{t}}+\beta_{2} \operatorname{lnPremium}_{\mathrm{t}}+\beta_{3} \ln \text { Export }_{\mathrm{t}}+\mathrm{u}_{\mathrm{t}}
\end{aligned}
$$

\subsection{Data}

This study uses a data sample from between 1980 and 2014. The GDP, exports, and total fixed assets investment volume is sourced from both the China Statistical Yearbook and the Wind Financial Information Database. The information for the total premiums comes from the China Insurance Yearbook, and the HHI is calculated according to data from the China Insurance Yearbook and Equation (2).

\section{RESULTS AND DISCUSSION}

Tables 3 and $\mathbf{4}$ summarize the empirical results.

According to Table 3, compared to the mean, the standard deviation of 1GDP, 1Premium, and lExport are all above 1 , indicating a relatively significant annual volatility in all three of these measures. This is further supported by the 
Table 3. Descriptive statistics.

\begin{tabular}{|c|c|c|c|c|}
\hline Independent variables & IGDP & IHHI & IPremium & IExport \\
\hline \hline Mean & 10.988 & 8.177 & 5.583 & 7.557 \\
\hline Median & 11.283 & 8.216 & 6.065 & 7.511 \\
\hline Maximum & 13.364 & 8.670 & 8.882 & 10.062 \\
\hline Minimum & 8.423 & 7.413 & 1.526 & 5.199 \\
\hline S.D. & 1.557 & 0.394 & 1.850 & 1.589 \\
\hline
\end{tabular}

Table 4. Regression results with GMM method.

\begin{tabular}{|c|c|c|}
\hline & (I) & (II) \\
\hline Independent variables & $\begin{array}{c}\text { Homoscedasticity } \\
\text { hypothesis }\end{array}$ & Heteroskedasticity hypothesis \\
\hline Constant & $\begin{array}{l}2.787^{* *} \\
(4.572)\end{array}$ & $\begin{array}{l}2.865^{*} \\
(4.900)\end{array}$ \\
\hline 1HHI & $\begin{array}{c}-0.141^{* * *} \\
(0.046)\end{array}$ & $\begin{array}{c}-0.142 * * * \\
(0.049)\end{array}$ \\
\hline 1Premium & $\begin{array}{c}0.291 * * * \\
(0.074)\end{array}$ & $\begin{array}{c}0.303 * * * \\
(0.072)\end{array}$ \\
\hline 1Export & $\begin{array}{c}1.006 * * * \\
(0.124)\end{array}$ & $\begin{array}{c}0.995^{* * *} \\
(0.131)\end{array}$ \\
\hline Adjusted $R^{2}$ & 0.986 & 0.986 \\
\hline
\end{tabular}

Standard errors are in parentheses. $* * *, * *$, and $*$ indicate significance at the $1 \%, 5 \%$, and $10 \%$ levels, respectively.

substantial differences between the minimums and maximums. However, the standard deviation of $1 \mathrm{HHI}$ is only 0.394, demonstrating that the level of concentration in the property insurance market in China is declining slowly.

To further support the effectiveness of regression analysis, it is necessary to examine the stationarity of the model. The p-values of the variables are 0.000 using the ADF test to reject the null hypothesis at the $1 \%$ level of significance; thus, the variables used in this study are stable.

Additionally, the results of the Hausman test also reject the null hypothesis at the $1 \%$ level, implying that there may be a problem with endogeneity in this model. Therefore, the OLS method is replaced with a Two-Step SYS-GMM method. Moreover, considering the endogenous relationship between total exports and GDP, the logarithms of the first- and second-order lag variables of total fixed assets investment volume (lFinvest) are used as the instrumental variables of the independent variable lExport. Since total exports change annually, and are highly correlated with total fixed assets investment volume, there is no impact on the past GDP.

Table 4 reports the results from the estimations for Equation (4) under the homoskedastic and heteroskedastic hypotheses, respectively. First, the results confirm that the variables are appropriate as the over-identification test returns a p-value of 0.385 , indicating the effectiveness of the instrumental variables. Generally, under the hypotheses of ho- moskedasticity and heteroskedasticity, the F-values are both 0.000 , indicating that the model is significant as a whole. Moreover, the adjusted R-square is 0.986 , showing that this model has an extremely high goodness of fit. Thus, the variables and the model are appropriate. We can observe that both coefficients of the independent variables and the significance levels meet basic standards.

The results from column (II) in Table 4 show that the $1 \mathrm{HHI}$ coefficients are negative and significant at the $1 \% \mathrm{lev}-$ $\mathrm{el}$, indicating that a one-unit decline in the degree of industrial agglomeration in the property insurance industry could improve GDP by nearly $14.2 \%$, in addition to improving market competitiveness. However, there is no doubt that the property insurance market is still in a high oligopolistic situation overall, compared to automobile insurance, which is compulsory and remained high for a long time, and the other types, namely insurance of contents and cargo transportation insurance, among others, are extremely low. On the other hand, large-scale domestic enterprises control most of the property insurance market, though enterprises with foreign investment could take a small part. For example, the automobile liability insurance business has been open to foreign companies since May 1, 2012.

China's central government should provide greater support and preferential treatment for enterprises with foreign investment, as it is currently pursuing a policy of opening the 
market further and stimulating market vitality. As the degree of concentration declines, there are side effects that will also stimulate economic growth in China.

The slightly larger IPremium coefficient $(0.303)$ in column (II) compared to column (I) implies a notable positive relationship with GDP, indicating that as the industry develops more effectively, there will be increased economic growth. In addition, the lExport coefficients are remarkably positive at the $1 \%$ level, indicating a highly significant impact on GDP growth, especially in the short term. Therefore, China's central government should pay more attention to the chronic trade surplus as well as the balance of foreign trade based on the premise of export expansion. These conclusions echo similar findings in other studies [12], and actual conditions in China.

\section{CONCLUSION}

This study first calculates the HHI for the property insurance market in China between 1980 and 2014, which shows the historic evolution and current situation in this market in China, and indicates that this has some obvious monopolistic characteristics, far from perfect competition market. Then, this study applies the GMM method to analyze the relationship among economic growth, concentration in the property insurance market, total export volume, and total insurance premiums.

This study reveals that $\mathrm{HHI}$ is sensitive to variations in the GDP in China, and that if other factors remain the same, a decrease in HHI benefits economic growth. Additionally, improvements to the property insurance market improve the probability that GDP will increase. Finally, developing foreign trade can significantly promote economic growth. Ultimately, this study finds that the degree of concentration in the property insurance industry has a notable influence on domestic economic growth.

\section{CONFLICT OF INTEREST}

The authors confirm that this article content has no conflict of interest.

\section{ACKNOWLEDGEMENTS}

Declared none.

\section{REFERENCES}

[1] H.Q. Zhao, and H. Wu, "The effect of diversification and competition on performance for Chinese property - liability insurers," Econ Management J., vol. 1, PP. 101-109, 2014.

[2] J.F. Outreville, "The economic significance of insurance markets in developing countries," J. Risk \& Ins, vol. 57, pp. 487-498, 1990.

[3] P. Martin, and G.I. Ottaviano, "Growing location: Industry location in a model of endogenous growth," Europ Econ Rev, vol. 43, no.2, pp. 281-302, 1999.

[4] M. Fuijita, and J.F. Thisse, "Economics of agglomeration: Cities, industrial location, and regional growth," Cambridge: Cambridge University Press 2002.

[5] M. Brulhart, and F. Sbergami, "Agglomeration and growth: Empirical evidence," ETSG Working Paper, [Online]. [Cited: 152013. Available from: www.Hec.unil.ch/mbrulhart/papers.

[6] F. Sbergami, "Agglomeration and economic growth: Some puzzles," HEI Working paper, no. 2, 2002.

[7] M. Zhu, Y. Lv, and C. Kui, "The determinants of demand for corporate insurance in China: Empirical analysis with panal data at province level," J Finance Res, vol. 12, pp. 67-79, 2010.

[8] Q.X. Sun, and J.S. Zhu, "An exploration with the appraisal parameter system of the development of the insurance industry," Ins Stud, vol. 2, pp. 18-23, 2008.

[9] L. Tian, J. Gao, "Booster or Stabilizer: an empirical analysis on the function of insurance industry to economic growth," Ins Stud, vol. 3, pp. 26-35, 2011.

[10] Z.J. Li, X.X. Xue, and J.M. Su, "The evaluation model of fixed asset investment's stimulation to per capital GDP," J Inn Mong Agric Univ, vol. 34, no. 6, pp. 174-176, 2013.

[11] L.Z. Song, "Review of the relation between China's fixed assets investment and the economic growth in 1980-2010," Macroecon, vol. 11, pp. 17-21, 2011.

[12] Y. Yuan, and Y. Tan, "Dynamic panel GMM analysis of Chinese Demand for property insurance and the insurance industry concentration," Hainan Finance, (monthly) vol. 4, no. 66-69, 2013.

[13] L. Li, and Y.F. Li, "Analysis of the market structure of property insurance in China," Journal of insurance professional college (bimonthly) vol. 2, pp. 17-20, 2013.

Received: May 26, 2015

Revised: July 14, 2015

Accepted: August 10, 2015

(C) Qianqian Li; Licensee Bentham Open.

This is an open access article licensed under the terms of the (https://creativecommons.org/licenses/by/4.0/legalcode), which permits unrestricted, noncommercial use, distribution and reproduction in any medium, provided the work is properly cited. 